\title{
TECHNOLOGY, UNEMPLOYMENT, AND RELATIVE WAGES IN A GLOBAL ECONOMY
}

Donald R. Davis

Working Paper 5636

\section{NATIONAL BUREAU OF ECONOMIC RESEARCH 1050 Massachusetts Avenue \\ Cambridge, MA 02138 \\ June 1996}

I would like to acknowledge, without implication, the helpful comments of Richard Brecher, Lawrence Katz, John Leahy, and Jeff Williamson. I am also grateful for the support for this project from the Harvard Institute for International Development. This paper is part of NBER's research program in International Trade and Investment. Any opinions expressed are those of the author and not those of the National Bureau of Economic Research.

(C) 1996 by Donald R. Davis. All rights reserved. Short sections of text, not to exceed two paragraphs, may be quoted without explicit permission provided that full credit, including () notice, is given to the source. 
NBER Working Paper 5636

June 1996

\title{
TECHNOLOGY, UNEMPLOYMENT, AND \\ RELATIVE WAGES IN A \\ GLOBAL ECONOMY
}

\begin{abstract}
Arguably the most important development in recent decades in US factor markets is the decline in the relative wage of the unskilled. By contrast, in Europe it is undoubtedly the rise and persistence of unemployment. Technology has been identified as a key reason for the rising US wage inequality, while labor market rigidities are often cited as a key reason for European unemployment. This paper seeks to provide a unified account of these major factor market developments. It models the impact of technical change on relative wages and unemployment in a world in which one country has flexible and the other rigid labor market institutions. The results depart significantly but sensibly from what one would expect in a fully flexible wage world. A few stylized facts help to narrow the field to a few candidates to account for these factor market developments.
\end{abstract}

Donald R. Davis

Department of Economics

Harvard University

Cambridge, MA 02138

and NBER 


\section{Introduction}

\subsection{A Global Approach}

Over the past twenty years factor market developments in the United States and much of Europe have contrasted sharply. ${ }^{1}$ Arguably the most important development in the United States is the sharp decline in the relative wage of the unskilled. By contrast, in Europe the most important development is undoubtedly the rise and persistence of unemployment. A growing body of research traces the growing wage inequality in the United States to technical change. One interpretation of the rising unemployment in Europe focuses on labor market rigidities.

There is an important respect in which these accounts are unsatisfying. The United States and Europe are part of a single global economy, and they share a common technological regime. Yet research has focused on the cases one at a time. This suggests that an important check of the robustness of these accounts is to examine them in a unified model of a trading world. It must provide a general equilibrium determination of wages and unemployment, while allowing for cross-country differences in the structure of labor market institutions. The model of Davis (1996) provides just such a framework. The present paper considers the implications of technical change for the evolution of wages and unemployment in a global trading equilibrium.

This study has a single central message. Allowing for even one of the countries in a trading world to have rigid labor market institutions fundamentally alters the link between technical change and factor returns for the whole world. At times the results will be exactly contrary to those derived in a fully flexible wage setting. Nonetheless our flexible wage results

${ }^{1}$ See e.g. Freeman and Katz (1995) and CEPR (1995). 
continue to provide insight. They are here key to understanding movements in employment in the economy with real rigidities. ${ }^{2}$

From a wide array of comparative statics considered, the paper identifies just a few that seem to be of real interest. These hold promise of providing a unified account of the major factor market developments of recent decades in both the United States and Europe.

\subsection{Background}

The role of technical change in giving rise to observed movements in skilled to unskilled wages has been a source of great interest and controversy. Some researchers, as Berman, Bound, and Griliches (1994), have identified technical change as the central cause for the decline of unskilled relative wages in the United States. This viewpoint has been supported by the work of Lawrence and Slaughter (1993), and Berman, Machin and Bound (1996), among others. A contrary view has been advanced by Leamer (1994), with a more mixed picture emerging in Leamer (1995).

This discussion has focused on the role of labor-saving technical change, with the computer revolution particularly in mind. However there has been some dispute about the relevance of factor versus sector bias in technical change, as in Leamer (1995) and Krugman (1995). Leamer focused on a case in which the United States is a small country, and in which technical change is local. Krugman focused on a case in which the United States is a large country

${ }^{2}$ The departures from conventional flexible wage results here underscore the importance of considering all three elements of the Freeman, Katz (1995) Supply-Demand-Institutions paradigm within a unified general equilibrium framework. 
and the technical change is global. In the former, the sector bias of technical change is key, whereas in the latter conditions are specified under which only the factor bias matters for the qualitative effects on relative wages. Freeman and Katz (1995) concur with Krugman that many of the major technical innovations should be looked on as global rather than local shocks. Thus if one also wants to account for the different experience of Europe and America regarding wages, one cannot look only at technology. If technical progress is to be part of the explanation, then it must be via the form in which local labor institutions mediate the shocks.

There are a few stylized facts that will prove useful in considering the theory [see Freeman and Katz (1995)]. (1A) The relative position of unskilled in the United States has deteriorated more sharply in the US than in Europe. (1B) A stronger version of this would state that the relative wage of the unskilled declined in the United States while it was unchanged in Europe. (2) Unemployment in Europe rises. (3A) Some work, as in Lawrence and Slaughter (1993), has suggested that this occurred at unchanged relative goods prices. (3B) Other work, such as Krueger (1995) and Sachs and Shatz (1995) has argued that the relative price of unskilled intensive goods has fallen. (4) Measured skill intensities of production have been rising, even where the relative wage of skill has risen. We will take this in a weak form, excluding cases in which skill intensity falls in all sectors.

The paper has three additional sections. Section 2 outlines the global trading model. Section 3 develops some basic concepts regarding the links between technical change and factor returns. It then derives the implications of technical change for relative wages and unemployment when one country features a rigid minimum wage. Section 4 concludes. 


\section{A Simple Model of Trade and Unemployment}

In this section we develop a simple model on which to found our analysis of the effects of technical change on trade, wages and unemployment. The basic structure of the economy will be that of the canonical Heckscher-Ohlin model. This is amended to allow for a rigid real wage for the unskilled, in the spirit of Brecher (1974). ${ }^{3}$ The general equilibrium links between endowments, goods prices and factor prices, and the link to the level of unemployment are illustrated in a diagram from Davis (1996). Conditions are noted which allow even economies with sharply divergent factor market institutions to feature factor price equalization. ${ }^{4}$ Since many of the comparative statics that we later consider will lead factor price equalization to break down, we also develop an import demand, export supply framework for determining equilibrium. This emphasizes that in the presence of factor -- hence goods -- price rigidities, equilibrium in markets is attained by movements in the level of employment.

${ }^{3}$ In choosing this approach, we abstract from the important issue of the source of wage rigidity. This is justified by the transparency that it allows in examining the already complex links between technology, trade, factor prices and unemployment. One more explicit approach is to treat the minimum wage as the result of a simple game between governments, as in Davis (1996). This remains a direction for additional research.

${ }^{4}$ Using a model which features factor price equalization as a benchmark is justified by the great simplicity it yields to the analysis. However, as Leamer (1994) has emphasized, the FPE result implies that conditional on goods prices, technology, and diversified production, factor prices are independent of local factor supplies. The work of Freeman and Katz (1995), as well as that of Robbins (1996), suggests that local relative factor supplies $d o$ matter for relative wages. This suggests the value of pursuing extensions to the present study in directions in which local factor supplies do matter. 
Consider the integrated world economy. ${ }^{5}$ The structure of this economy is the simple Heckscher-Ohlin model, except that employment of unskilled labor will be subject to a binding minimum wage. There are two goods, $X$ and $Y$. Let $P$ be the relative price of $X$ in terms of $Y$. We assume that preferences of all consumers are identical and homothetic. Thus the ratio of $X$ to $Y$ consumed depends only on relative goods prices. Technologies are constant returns to scale. We assume that at all factor price ratios, and for all comparative statics on technology, $\mathrm{X}$ is the relatively skill intensive good. Both goods and factor markets are perfectly competitive.

The goods are produced with skilled and unskilled labor, available in fixed supply given by $H$ and $L$. Since the skilled wage is assumed flexible, skilled labor will always be fully employed. Market clearing requires:

$$
H_{X}+H_{Y}=H
$$

With a minimum wage for unskilled labor above the market clearing level, unskilled labor will not be fully employed. Letting $\mathrm{N}$ be world unskilled employment, $\mathrm{U}$ be the number of unemployed, and $L$ the number of unskilled, the factor market constraint is that:

$$
N_{X}+N_{Y}+U=N+U=L
$$

The contrast between the flexible and rigid real wage worlds is summarized in a simple diagram from Davis (1996), appearing as Figure 1. Two relations suffice to describe the essentials of the global economy. The first can be thought of as a "Heckscher-Ohlin" mapping between the relative world endowment, $h \equiv H / L$, and the equilibrium relative goods price, $P$. This appears in

${ }^{5}$ Dixit and Norman (1980) turn the parable of Samuelson (1949) into a powerful analytic device. They establish conditions under which a full employment world with trade but no factor mobility replicates the "integrated equilibrium" of an economy with perfect goods and factor mobility. Davis (1996) extends this to the case in which one country has unemployment (due to rigid real wages) while the other does not. 
quadrant one, and has the sensible result that a world relatively more abundant in skill will have a lower relative price of the skill intensive good. The second relation can be thought of as a "Stolper-Samuelson" mapping between relative goods prices and factor prices. While this is typically written as a relation with relative factor prices, it is more convenient to depict it as a relation between the goods price, $P$, and the wage of the unskilled, $w_{\mathrm{L}}$. This appears in quadrant 2 . This has the sensible interpretation that the wage of the unskilled is directly tied to the relative price of the good that employs the unskilled relatively intensively. Heuristically, one can think of the path of determination in the flexible wage economy as moving from the exogenous world endowments to the equilibrium goods price, and thus to establish the return for unskilled labor.

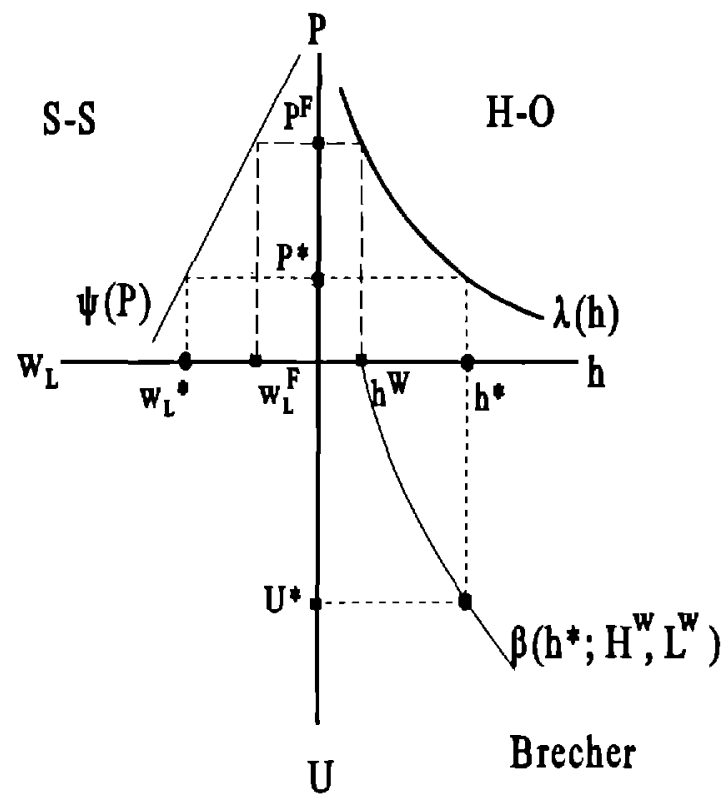

Figure 1 Unemployment in General Equilibrium

However this path is not available when there is a rigid minimum wage for the unskilled at a level $\mathrm{w}_{\mathrm{L}}{ }^{*}$ above the flexible wage, $\mathrm{w}_{\mathrm{L}}{ }^{\mathrm{F}}$. The Stolper-Samuelson relation continues to hold 
exactly. If in equilibrium the unskilled wage is to be $w_{L}{ }^{*}$, then this must be supported by an equilibrium goods price of $\mathrm{P}^{*}$. But the Heckscher-Ohlin relation holds now not in terms of endowments, but in terms of employed factors. If the equilibrium goods prices are to be $\mathrm{P}^{*}$, then the employment composition must be at $h^{*}>h$. Since all skilled labor is employed, due to its flexible wage, equilibrium requires that unemployment among the unskilled rise to the point that employed factors are in the ratio $h^{*}$. Given the world endowment of skilled and unskilled labor, this will determine a precise level of unemployment. This can be done for each level that the minimum wage could be set at. This gives rise to what I have termed the "Brecher" relation, after Brecher (1974), which appears in quadrant four.

The conditions under which a world with distinct countries linked by goods trade replicates this integrated world economy is detailed in Davis (1996). A key result is that in spite of the institutional differences, and the fact that unemployment arises only in the country that implements the minimum wage, free trade in commodities leads to complete factor price equalization. The reason is that in spite of the institutional differences, trade equates goods prices, hence all producers face the same zero profit conditions, which in turn yield equal factor prices.

Here we develop a two country version of this model that builds on these insights. ${ }^{6}$ But since we will consider comparative statics that introduce cross-country differences in technologies, our framework must be robust to failures of factor price equalization. Consider a world with two countries, which following Krugman (1995) we will call America and Europe. The essential difference between America and Europe lies in their factor market institutions. America is a flexible wage, full employment economy. Europe has a rigid minimum wage for the

\footnotetext{
${ }^{6}$ We assume here and throughout that both countries are always diversified in production.
} 
unskilled set at $\mathrm{w}_{\mathrm{L}}{ }^{*}$ in terms of the numeraire. The two countries have conventional market clearing conditions for skilled labor. But these conditions look different for America and Europe in the market for unskilled labor. For America:

$$
L_{X}^{A m}+L_{Y}^{A m}=L^{A m}
$$

But in Europe, the condition instead appears as:

$$
N_{X}^{E}+N_{Y}^{E}+U=N^{E}+U=L^{E}
$$

A key insight to the international equilibrium is that with wages -- and so goods prices -fixed, it is unemployment that adjusts to clear the market. Thus, we can depict the international equilibrium in an import demand/export supply framework with European unemployment on the vertical axis. This appears as Figure 2.

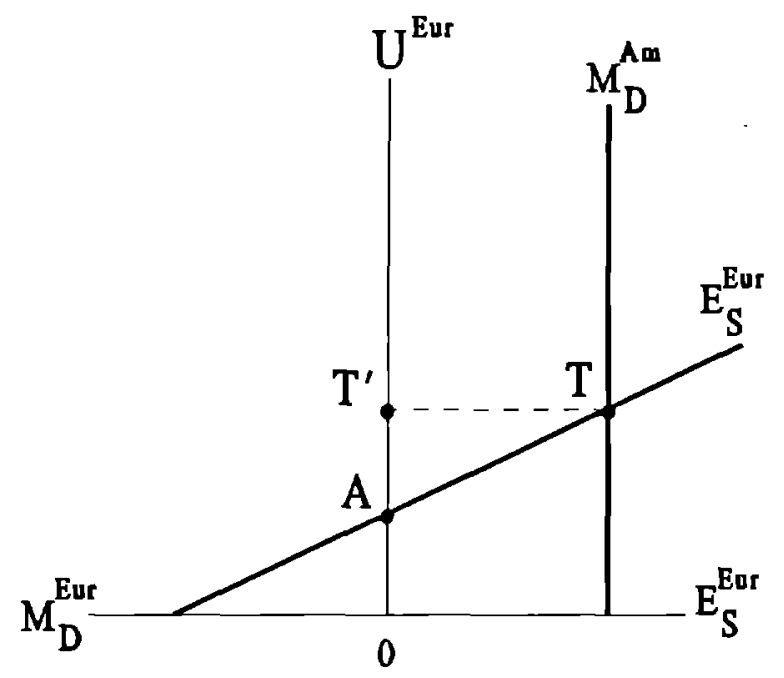

Figure 2 The Trading Equilibrium 
Where the minimum wage $\mathrm{w}_{\mathrm{L}}{ }^{*}$ binds, goods prices must be $\mathrm{P}^{*}$. But since American import demand depends only on the price $\mathrm{P}^{*}$, it is independent of the level of European unemployment. The role that European unemployment plays is to make the unskilled good sufficiently scarce so as to support the price $\mathrm{P}^{*}$. Thus at this price, Europe is obliged to meet whatever excess demand or supply the rest of the world may present to it at $\mathrm{P}^{*}$. Given our assumptions on demand and technology, European unemployment rises linearly with the world excess demand for X. Equilibrium is determined at point $T$, with unemployment at the level $\mathrm{T}^{\prime}$.

The case depicted in Figure 2 is the benchmark case developed in Davis (1996), in which America and Europe have identical endowments. In this case, trade with America doubles European unemployment from its autarky rate, moving from $A$ to $T^{\prime}$. More generally, depending on the position of the American import demand curve, trade could raise or lower European unemployment. $^{7}$

\section{Technical Change: Global and Local}

\subsection{A Two-Sector Leontief Model}

The effect of technical change on factor prices in the two sector general equilibrium model has a variety of facets to consider. ${ }^{8}$ These include whether the change is (geographically) local or global, the sector bias, the factor bias, elasticities of goods supply and demand, and factor

${ }^{7}$ None of the results derived in this paper depend on the pattern of trade, or equivalently, whether trade with America raises or lowers European unemployment

${ }^{8}$ The classic analysis of technical change in the two-sector general equilibrium model with flexible wages and full employment is Findlay and Grubert (1959). 
substitution. ${ }^{9}$ For analytic purposes, it is convenient to begin with a model of Leontief

technologies.$^{10}$ As well, throughout we restrict attention to three cases of factor bias -- neutral, pure labor saving, and pure skill saving.

A simple setting for thinking about the links between technical change and factor returns is that of Mussa (1979) [see Figure 3]. We consider the case of two goods produced under perfect competition and constant returns to scale. This yields two conditions equating prices and unit costs for the respective goods. The concavity of the cost function assures that in factor price space the upper contour sets are (weakly) convex. In the case of Leontief technologies, the respective zero profit conditions are linear.

$$
P=c_{X}\left(w_{H}, w_{L}\right)=w_{H} a_{H X}+w_{L} a_{L X} \quad l=c_{Y}\left(w_{H}, w_{L}\right)=w_{H} a_{H Y}+w_{L} a_{L Y}
$$

When production is diversified, equilibrium factor prices are determined by the intersection of the zero profit curves in factor price space.

${ }^{9}$ If technology was a pure public good, freely available to all, then the local vs. global distinction would not be relevant -- all shocks would be global. And no doubt one of the important shocks that we would want to think about -- the microcomputer revolution -- is in important respects global. Nevertheless, careful estimation has confirmed the existence and importance of cross-country technical differences at the industry level, as well as variations in these across time [see Jorgenson (1995)].

${ }^{10}$ We consider the effects of factor substitution in Section 3.4 below. The restriction to Leontief technologies here was made for three reasons. First, making this restriction allows for a greatly simplified analysis of a number of points that have remained opaque in previous treatments. A similar restriction has been made in sections of Leamer (1995) and Krugman (1995). Second, the work of Lawrence and Slaughter (1993) showing steady rises in skill intensity across all sectors even as relative skilled wages rose suggests that factor substitution is not the dominant element of the story. Finally, we will demonstrate below that of the cases in which the principal qualitative results depend on factor substitution, none satisfy the set of stylized facts that we use as a screen. 
A few general results from the analysis of technical change in a flexible wage economy will be useful in considering the effect on relative wages of our experiments. When goods prices are fixed, the qualitative impact on relative factor prices is entirely determined by the sector in which the technical change occurs, independent of the factor bias. For example, technical progress in $\mathrm{X}$ always leads to an outward movement of the zero profit curve. As is evident from Figure 3, the relative skilled wage always rises as a result. This point has been emphasized by Leamer (1994).

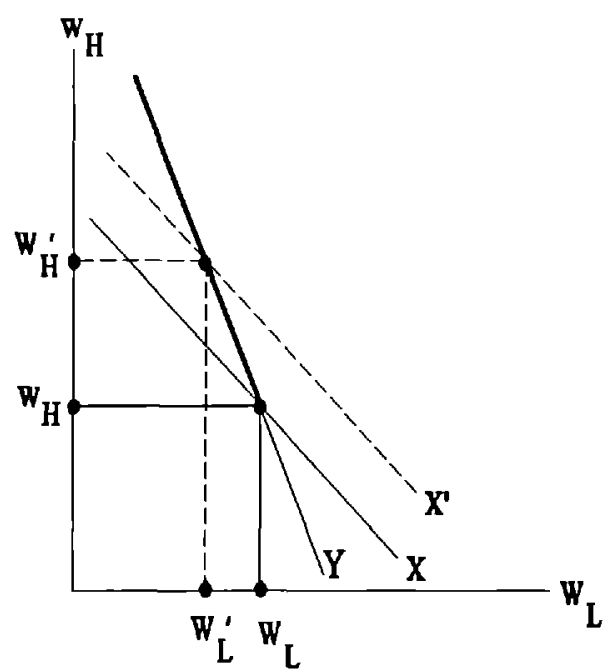

Figure 3 Neutral Technical Progress in X at Fixed Prices

When goods prices do adjust endogenously, this bifurcation by sector need not hold. The reason is that changes in goods prices may mute or reverse the impact effect of technical change on factor prices. The first step towards understanding this is to determine how the technical change affects output supplies and demands at unchanged prices, hence to determine the direction in which goods prices will change. One can then identify the cases in which price changes reinforce the impact effect on the unskilled wage, as well as those in which it may mute or reverse these effects. The induced price changes will only mute the impact effect when demands and 
supplies are sufficiently elastic -- what we will call the "elastic case." In the contrary "inelastic case," the price movement is sufficient to reverse the impact effect on the unskilled wage. The possibility that induced price changes may reverse the impact effect of technical change on factor prices figures prominently in the discussion of Krugman (1995).

Here Leontief technologies allow a simple conclusion. ${ }^{11}$ Neutral technical progress at fixed goods prices always raises output of the progressing sector, while leaving output of the other sector unchanged. The reason is that with Leontief technologies, neutral progress does not affect the sectoral allocation of resources. Thus output rises only in the progressing sector. Since the implied change in income will, with homothetic preferences, raise demand for both goods proportionally, it follows that the relative price of the progressing sector's good must fall. So neutral technical change always leaves open the possibility that endogenous price changes will reverse the impact effect on relative factor prices. ${ }^{12}$

Pure labor saving technical progress, in either sector, always raises the output of the labor intensive good at unchanged prices, while reducing output of the skill intensive good. We illustrate this for the case of progress in the $X$ sector in Figure 4. Consider the problem in two steps. For the moment, we fix the resources allocated to $Y$ (at B), and so leave $Y$ output unchanged. Now note that a pure labor saving change in $X$ means that the initial level of output in $X$ can be produced with the same level of employed skill and less labor (a move from $\mathrm{A}^{\prime}$ to $\mathrm{A}^{\prime}$ ). Of

${ }^{11}$ For a complete list of results with a flexible wage, see Appendix A.

${ }^{12}$ Krugman (1995) provides a convenient boundary case. When technology is Leontief, technical progress is global, both countries are diversified, and preferences are Cobb-Douglas, then the induced price changes exactly offset the impact effect of technical progress on relative wages. 
course, this labor will in equilibrium be employed. We can invoke the Rybczynski theorem, which here implies that the output of labor intensive $Y$ will rise while that of $X$ declines at fixed prices. Since with homothetic demand the incremental income has raised demand for both goods at the initial prices, this implies an excess supply of the labor intensive good. Its relative price must fall, which then works toward a rise in the relative skilled wage. Thus, in our example of labor saving technical change in the $X$ sector, the goods price movement reinforces the rise in the relative skilled wage.

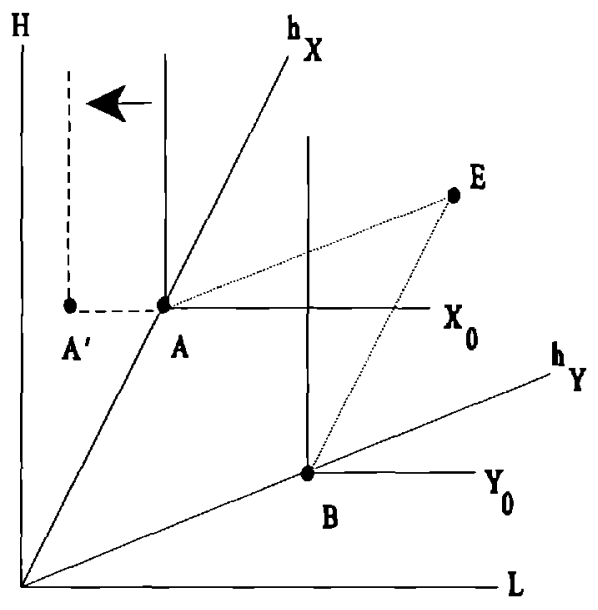

Figure 4 Labor Saving Progress in X:

Output Effects

If instead the labor saving progress were in the labor intensive sector, then the price movements instead would mute or reverse the impact effect of technical change. A parallel story can be told for pure skill saving technical change. This depresses the price of the skill intensive good, so reinforces the decline in the relative skilled wage if the progress is in the $Y$ sector, but mutes or reverses the impact effect of skill saving technical progress in the $X$ sector. 


\subsection{Technical Change, Wages, and Unemployment}

We now consider the effects of technical change for the case in which Europe imposes a minimum wage.$^{13}$ Our base case assumes that technologies in America and Europe are initially identical. We first consider technical change that is global in scope, and then change that is localized in Europe or America.

The effects of global technical change are quite similar to those described above. The only amendment that we need to consider is that any implied changes in the unskilled wage must now be met with changes in unemployment that return the unskilled wage to its initial level. We saw above that there were two broad cases to consider. In the elastic case, the unskilled wage is always depressed by progress of whatever kind in the $X$ sector. Accordingly global technical progress in $X$ would require a rise in European unemployment to meet the wage target. Progress in $Y$, by contrast, would reduce unemployment. In the inelastic case, the induced price changes may reverse the impact sectoral effects on factor prices. In this case, at unchanged employment, the unskilled wage will fall with all labor saving technical change (in $X$ or $Y$ ), and with neutral technical change in the $Y$ sector. Accordingly, a rise in European unemployment will be required to again attain the target wage. By contrast, all skill saving technical change, and neutral technical change in the $X$ sector will reduce European unemployment. In the full equilibrium, price changes will always fully offset the impact effect on factor prices. Thus technical change in $X$ of whatever factor bias will in full equilibrium always lead to a fall in the price of $X$ [See Figure 5]. As well, technical progress in $Y$ always leads in full equilibrium to a rise in the price of $X$ which returns the

\footnotetext{
${ }^{13} \mathrm{~A}$ complete set of results is detailed in Appendix B.
} 
unskilled wage to its initial level. Accordingly, none of the global shocks satisfy the LawrenceSlaughter criterion that relative goods prices should be unaffected. Nonetheless, all forms of global progress in the Y sector satisfy the alternative Krueger-Sachs-Shatz criterion that the relative price of the unskilled good declined.

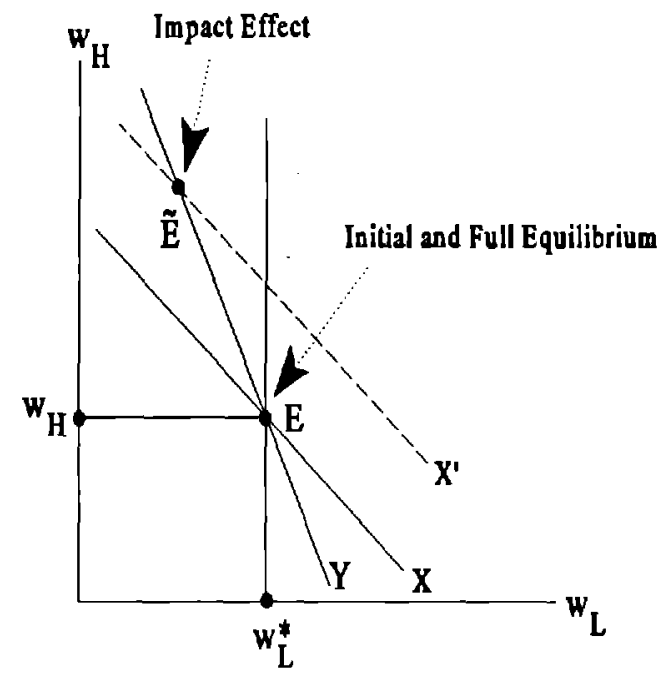

Figure 5 Global Neutral Technical Progress in $\mathrm{X}$

Because incipient rises or declines in the unskilled wage are met with accommodating changes in unemployment, the level of the unskilled wage is not affected by global technical progress. The full equilibrium effect on relative factor prices depends exclusively on the sector of technical progress. If progress is in the $X$ sector, then the relative wage will be unchanged; if in the $Y$ sector, then the relative wage of the skilled will rise. This is precisely opposite to the conclusion that one would have in a model with fixed prices and no unemployment [see Leamer (1995)]. 
We may also identify cases of global technical progress in which the European unemployment rate rises and the relative wage of the skilled rises. This combination occurs only in the cases of neutral or labor saving technical change in the $Y$ sector in the inelastic case. Recall also that since our general system is consistent with factor price equalization, that the global technical progress will not help us to understand divergent patterns of wage evolution between Europe and America. ${ }^{14}$

Consider now the case of technical progress which is localized in Europe. The basic analysis outlined above continues to hold for Europe, with one amendment. There will be a smaller supply shock for a fixed magnitude of technical change, hence the likelihood of price changes reversing the impact effect on factor prices is diminished. This will tend to emphasize the sectoral nature of technical change relative to its factor bias. Now consider the impact of local European technical change on America. Since America does not experience any technical change, the full impact on its relative factor prices is determined a la Stolper-Samuelson by the equilibrium changes in goods prices. Thus the relative skilled wage in America will rise as the equilibrium relative price of $X$ rises. A curious consequence is that local European technical change gives rise to a magnified relative wage response in America relative to that in Europe. From above, the European relative skilled wage rises with local technical progress in the $Y$ sector, and is unaffected by progress in the $X$ sector. The effect of local European technical progress on America is yet more dramatic. When this progress is in the $Y$ sector, the American relative skilled wage rises faster than in Europe, and when in the $X$ sector actually declines. If we restrict

${ }^{14}$ Of course, a sharp result such as this depends on the full set of assumptions that underlie the conventional factor price equalization theorem. Departures from these assumptions, accordingly, may modify this conclusion. 
attention to cases in which European unemployment rises, the relative skilled wage in America rises, and in which this rise occurs more strongly than in Europe, then we have the cases of European local technical progress that is either neutral or labor saving in the $Y$ sector. As in the case of global technical progress, none of the cases of progress in Europe satisfy the LawrenceSlaughter criterion that relative goods prices remain fixed. All cases of European progress in $\mathrm{Y}$ satisfy the Krueger-Sachs-Shatz criterion that the relative price of the unskilled intensive good falls.

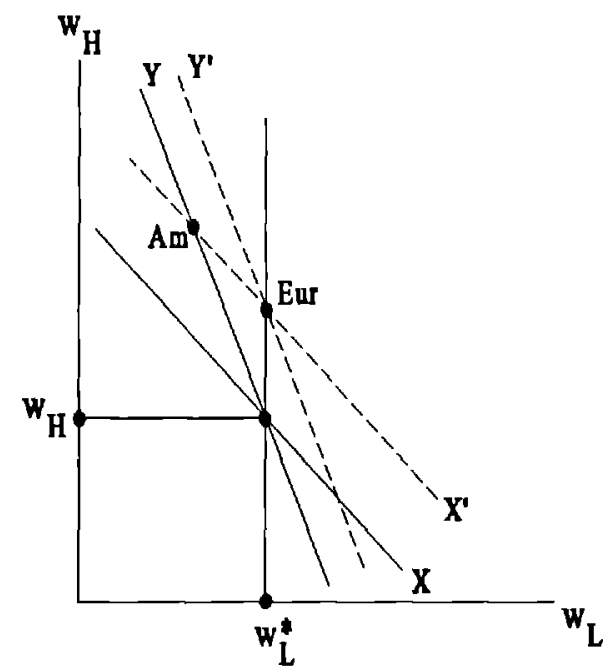

Figure 6 European Neutral Technical Progress in $\mathrm{Y}$

Finally, consider the case of local technical change in America. A first observation is that since Europe is not experiencing technical change, its commitment to the minimum wage will mean that in full equilibrium the goods price cannot change. Any induced excess supplies or demands at this price in America will be fully accommodated via changes in employment in Europe. Hence unemployment in Europe will rise as a result of all local American labor saving 
technical change as well as neutral technical change in the $Y$ sector. It will fall in the remaining cases. In all cases, European absolute and relative wages are unchanged. By contrast, in America, since goods prices are constant in equilibrium the changes in relative wages depend only on the sector in which technical change occurs, not its factor bias. Thus Leamer's suggestion that it is only the sector bias of technical change that matters is true for local American technical progress even when America is large in the world, so long as Europe is committed to its minimum wage. The relative skilled wage in America rises with technical progress of any variety in the $X$ sector, and conversely falls with progress in the $Y$ sector.

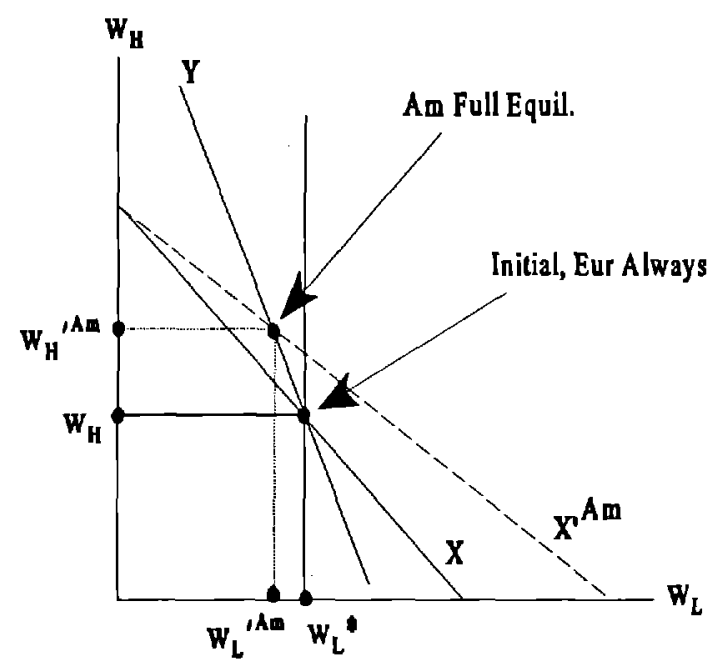

Figure 7 American Labor Saving Technical Progress in $\mathrm{X}$

The final case is what we may call the Lawrence-Slaughter-Leamer case [see Figure 7] This is the case of local American labor saving technical progress in the skill intensive $X$ sector. This leads to a rise in the American relative skilled wage, no change in the European relative skilled wage, a rise in European unemployment. The relative goods price is unchanged. 


\subsection{The Role of Factor Substitution}

To this point we have made the strategic assumption that technologies are Leontief. This greatly simplifies the analysis. However it can affect the qualitative results, so here we consider the cases where factor substitution matters. One manifestation of the simplicity of the Leontief framework is that it yields unambiguous predictions of the effects of technical progress on the terms of trade. When we allow for factor substitution we will need to reexamine this problem. We first return to our full employment specification, and then consider it within our America/Europe model with a fixed minimum wage and unemployment.

Where possible, we substitute away from the factor whose relative price has risen. This substitution tends to relieve the scarcity of that factor. At fixed goods prices, this implies that relative to the zero-substitution case, output will shift toward the good that uses this factor intensively. In some cases this only reinforces the effects described earlier, so has qualitatively the same effect as the Leontief case. This is true for all neutral technical progress, and for factorsaving progress in the sector that uses that factor intensively. However, this leaves two cases in which the output effects resulting from factor substitution oppose and may reverse those we have detailed earlier. This occurs in the cases of labor saving technical progress in the skill intensive sector, and skill-saving technical progress in the labor intensive sector.

Consider the case of labor saving technical progress in the skill intensive sector. At unchanged goods prices, the technical change raises the relative skilled wage. If technologies were Leontief, at fixed prices the labor saving progress would lead to a rise in the relative supply of Y. Here, though, the substitution away from higher-priced skill leads both sectors to economize on the use of skill. This substitution biases production toward $\mathrm{X}$, and given sufficiently elastic factor 
substitution could lead to a rise in the relative supply of $X$. Thus the relative price of $X$ in equilibrium would rise if factor substitution possibilities are poor, but fall if these possibilities are excellent. In the former case, the terms of trade movement reinforces the impact effect on factor prices. In the latter case, it opposes and potentially could reverse these effects. Thus labor saving technical progress in the skill intensive sector will tend to raise the relative skilled wage when factor substitution is poor. However, if factor substitution is excellent, it could depress the relative wage of the skilled. This is made more likely when substitution in demand across goods is poor. A parallel ambiguity could be derived for skill saving technical progress in the labor intensive sector. If factor substitution possibilities are poor, then the relative price of $\mathrm{X}$ will fall and the relative skilled wage will fall for sure. In the substitution possibilities are excellent, the relative price of $\mathrm{X}$ will rise, and this will counteract and perhaps reverse the impact effect which lowered the relative skilled wage.

It remains to consider the implications of these results in our full model with unemployment. We will continue to relate these changes to the stylized facts developed above. Consider first the case of labor saving technical progress in the skill intensive sector. Whether this progress is global, or localized in Europe or America, the new possibility opened up is that at the initial level of unemployment this could cause the European unskilled wage to rise. Thus, in equilibrium this could be associated with a fall in European unemployment. While this is an interesting observation, and not obvious, it also conflicts with the stylized fact that European unemployment has risen. Accordingly, we will rule these out as cases of interest.

Now consider the case of skill saving technical progress in the labor intensive sector. Whether this progress is global, or localized in Europe or America, the new possibility opened up 
is that at the initial level of unemployment this could cause the European unskilled wage to fall. Thus, in equilibrium this could be associated with a rise in European unemployment. This is in accord with the stylized facts. The equilibrium changes in relative wages, though, are exactly the same as previously for the various cases. When the progress is global, the relative skilled wage rises as sharply in Europe as America, violating one of our stylized facts. When this progress is localized in America, the relative skilled wage there actually declines, again violating one of our stylized facts. Finally, when the progress is localized in Europe, the relative skilled wage rises in Europe, but it rises yet more sharply in America. The one stylized fact that is violated by this case is that here skill intensity falls in both sectors. Accordingly, we can conclude that none of the cases that rely on factor substitution to establish qualitative results are consistent with the stylized facts we set out at the start.

\section{Conclusion}

The most important contribution of this paper is that it provides a unified framework for examining the role of technical change in the salient factor market developments in recent decades in the United States and Europe. It demonstrates that the mediation of local institutions may be crucial in understanding the qualitative effects of technical change on relative wages and employment for the world as a whole. These depart in important but sensible ways from what we would anticipate in a world of universally flexible wages. It also identifies the few specific patterns of technical change that satisfy a set of key stylized facts. Accordingly, it aims to sharpen the focus of the discussion relating technical change to movements in relative wages and employment. 
These points are developed in a stylized model of trade between a flexible wage America and a rigid real wage Europe. In spite of the simplicity of the framework, a number of strong results emerge: $:^{15}$

First, global technical progress never raises the relative wage of the unskilled. Moreover, for the economy in which the minimum wage is imposed, no technological progress -- local or global -- can raise the relative wage of the unskilled. This is not to say that the unskilled necessarily lose from technical progress. While they do not gain in relative wage terms, their real wage may be raised by technical progress. More importantly, the locus, sector, and factor bias of this change will be important in determining the impact on unemployment.

Second, global technical progress here will not help to account for divergent wage trends, even when accompanied by strongly differentiated factor market institutions. The reason, of course, is the factor price equalization result noted earlier.

Third, the qualitative change in relative wages does depend on whether the technical progress is global or local, and if the latter, in which country it is localized. However it does not depend on the factor bias of the technical change. This, however, does not suggest that it returns us to the simple small economy case of Leamer (1995). One reason is that the direction of the change in relative wages may appear perverse relative to that case. For example, we will see that when technical progress is localized in Europe, all forms of progress in the labor intensive good raise the relative wage of the skilled in both countries. While this particular result depends importantly on the good in which the minimum wage is specified, it does caution against assuming

${ }^{15}$ The results are stated here for the set of comparative statics examined. They assume that technologies are initially identical, that the minimum wage in Europe binds throughout, that relative factor intensities are unchanged, and that diversification of production is maintained. 
that the flexible wage results will be robust to the introduction of alternative specifications of the factor market institutions.

Fourth, the Leamer-Krugman discussion of the relevance of sector versus factor bias of technical change here maps precisely into a debate over the impact on unemployment. Thus both the sector and factor bias of technical change play important roles in accounting for movements in relative wages and unemployment.

Fifth, when technical progress is local, in either country, the American relative wage responds with systematically higher variance, regardless of the sector or factor bias of the change. The European commitment to the minimum wage shields it from the variable wage effects, but the pressures are absorbed through changes in employment.

Finally, the possibility of distinguishing technical change by sector, by factor bias, by local versus global, and by the strength of induced price effects, suggests an unmanageable number of cases to contemplate. However, if we use the few stylized facts sketched above, the theory identifies only a few candidates that can explain these facts. Two are what may be thought of as "Krugman" cases -- where induced price changes become a central part of the story. These include global neutral and labor saving technical progress concentrated in the unskilled intensive sector. This raises the relative skilled wage in both America and Europe, while also raising European unemployment. It accords with the Krueger-Sachs-Shatz view that the relative wage of the unskilled intensive good has fallen, rather than with the Lawrence-Slaughter view that it is unchanged. Its one drawback is that it does not help to account for the stronger rise of relative skilled wages in America. The second case is local European neutral and labor saving technical progress concentrated in the unskilled intensive sector. This is similar to the previous case, except 
that American relative skilled wages do rise more sharply than in Europe. The final case of particular interest is what may be termed the Lawrence-Slaughter-Leamer case, that of local American labor saving technical progress concentrated in the skill intensive sector. This raises the relative skilled wage in America, and leaves it unchanged in Europe. It accords with the view of Lawrence-Slaughter, rather than that of Krueger-Sachs-Shatz, in that relative goods prices do not change. 


\section{References}

Berman, E., Bound, J. and Giliches, Z. (1994) "Changes in the Demand for Skilled Labor within US Manufacturing: Evidence from the Annual Survey of Manufactures," Quarterly Journal of Economics, May, 109, 367-97.

Berman, E., Machin, S. and Bound, J. (1996) "Implications of Skill-Biased Technological Change: International Evidence," mimeo, March.

Brecher, Richard A. (1974) "Minimum Wage Rates and the Pure Theory of International Trade," Quarterly Journal of Economics, 88, No. 1, 98-116.

Center for Economic Policy Research [CEPR] (1995) Unemployment: Choices for Europe, in the series "Monitoring European Integration 5," London: CEPR.

Davis, Donald R. (1996) “Does European Unemployment Prop up American Wages?" Harvard Institute of Economic Research Discussion Paper 1752, March.

Dixit, Avinash K. and Norman, Victor F. (1980) Theory of International Trade, Cambridge: Cambridge University Press.

Findlay, Ronald and Grubert, Harry (1959) "Factor Intensities, Technological Progress and the Terms of Trade," Oxford Economic Papers 121.

Freeman, Richard B. and Katz, Lawrence F. eds. (1995) Differences and Changes in Wage Structures, Chicago: University of Chicago.

Jorgenson, Dale W. (1995) Productivity, Cambridge: MIT Press.

Katz, Lawrence F., et.al. (1995) "A Comparison of Changes in the Structure of Wages in Four OECD Countries," in Freeman, Richard B. and Katz, Lawrence F. eds. (1995) Differences and Changes in Wage Structures, Chicago: University of Chicago.

Krueger, Alan (1995) "Labor Market Shifts and the Price Puzzle Revisited," mimeo, Princeton University, October.

Krugman, Paul (1995) "Growing World Trade: Causes and Consequences," mimeo Stanford University, prepared for the Brookings Panel on Economic Activity, April 6-7, 1995.

Leamer, Edward (1995) "In Search of Stolper-Samuelson Effects Between Trade and US Wages" mimeo, Yale and UCLA.

Leamer, Edward (1994) “Trade, Wages and Revolving Door Ideas" NBER Working Paper No. 4716, April.

Mussa, Michael A. (1979) "The Two-Sector Model in Terms of its Dual: A Geometric Exposition," Journal of International Economics, 9, No. 4, 513-526.

Robbins, Donald (1996) "Trade, Trade Liberalization and Inequality in Latin America and East Asia -- Synthesis of Seven Country Studies," mimeo, Harvard Institute for International Development, March.

Sachs, Jeffrey and Shatz, Howard (1995) "International Trade and Wage Inequality in the United States," mimeo Harvard University, December 1995.

Samuelson, Paul A. (1949) "International Factor Price Equalization, Once Again," reprinted in Jagdish Bhagwati, ed., International Trade: Selected Readings, 2nd ed., (1987)

Cambridge: MIT. 
Appendix A: Changes Based on Various Assumptions of Locale, Sector, and Factor Bias of Technical Change. Case with a Flexible Wage

\begin{tabular}{|l|l|l|l|l|}
\hline $\begin{array}{l}\text { GLOBAL } \\
\text { No Unem. }\end{array}$ & Price & $\begin{array}{l}\text { wh/wl } \\
\text { Elastic }\end{array}$ & $\begin{array}{l}\text { wh/wl } \\
\text { Inelastic }\end{array}$ \\
\hline & SS & - & + & - \\
\hline $\mathrm{X}$ & N & - & + & - \\
\hline & S & + & + & + \\
\hline & SS & - & - & - \\
\hline $\mathrm{Y}$ & N & + & - & + \\
\hline & LS & + & - & + \\
\hline
\end{tabular}

\begin{tabular}{|l|l|l|l|l|l|l|}
\hline $\begin{array}{l}\text { Europe } \\
\text { Local, } \\
\text { No Unem. }\end{array}$ & Price & $\begin{array}{l}\text { wh/wl } \\
\text { America }\end{array}$ & $\begin{array}{l}\text { wh/wl } \\
\text { Europe } \\
\text { Elastic }\end{array}$ & $\begin{array}{l}\text { wh/wl } \\
\text { Europe } \\
\text { Inelastic }\end{array}$ & Ratio \\
\hline & SS & - & -- & + & - & - \\
\hline X & N & - & -- & + & - & - \\
\hline & LS & + & ++ & + & + & - \\
\hline & SS & - & - & -- & -- & + \\
\hline Y & N & + & ++ & - & + & + \\
\hline & LS & + & + & - & + & + \\
\hline
\end{tabular}

\begin{tabular}{|l|l|l|l|l|l|l|}
\hline $\begin{array}{l}\text { American } \\
\text { Nocal, } \\
\text { No Unem. }\end{array}$ & Price & $\begin{array}{l}\text { wh/wl } \\
\text { America } \\
\text { Elastic }\end{array}$ & $\begin{array}{l}\text { wh/wl } \\
\text { America } \\
\text { Inelastic }\end{array}$ & $\begin{array}{l}\text { wh/wl } \\
\text { Europe }\end{array}$ & Ratio \\
\hline & SS & - & + & - & -- & + \\
\hline $\mathrm{X}$ & $\mathrm{N}$ & - & + & - & -- & + \\
\hline & LS & + & ++ & ++ & + & + \\
\hline & SS & - & -- & -- & - & - \\
\hline $\mathrm{Y}$ & $\mathrm{N}$ & + & - & + & ++ & - \\
\hline & LS & + & - & + & + & - \\
\hline
\end{tabular}

Notation: $++(--)$ implies relatively stronger than a $+(-)$. 
Appendix B: Changes Based on Various Assumptions of Locale, Sector, and Factor Bias of Technical Change. Case With a Minimum Wage

\begin{tabular}{|l|l|l|l|l|l|l|l|}
\hline GLOBAL & & Price & $\begin{array}{l}\text { wh/wl } \\
\text { America }\end{array}$ & $\begin{array}{l}\text { wh/wl } \\
\text { Europe }\end{array}$ & Ratio & $\begin{array}{l}\text { U Elastic } \\
\text { Demand }\end{array}$ & $\begin{array}{l}\text { U Inel. } \\
\text { Demand }\end{array}$ \\
\hline & SS & - & 0 & 0 & 0 & + & - \\
\hline X & N & - & 0 & 0 & 0 & + & - \\
\hline & LS & - & 0 & 0 & 0 & + & + \\
\hline & SS & + & + & + & 0 & - & - \\
\hline Y & N & + & + & + & 0 & - & + \\
\hline & LS & + & + & + & 0 & - & + \\
\hline
\end{tabular}

\begin{tabular}{|c|c|c|c|c|c|c|c|}
\hline $\begin{array}{l}\text { Europe } \\
\text { Local }\end{array}$ & & Price & $\begin{array}{l}\text { wh/wl } \\
\text { America }\end{array}$ & $\begin{array}{l}\text { wh/wl } \\
\text { Europe }\end{array}$ & Ratio & $\begin{array}{l}\text { U Elastic } \\
\text { Demand }\end{array}$ & $\begin{array}{l}\text { U Inel. } \\
\text { Demand }\end{array}$ \\
\hline & SS & - & - & 0 & - & + & - \\
\hline \multirow[t]{3}{*}{$x$} & $\mathbf{N}$ & - & - & 0 & - & + & - \\
\hline & $\mathbf{L S}$ & - & - & 0 & - & + & + \\
\hline & SS & + & + & + & + & - & - \\
\hline \multirow[t]{2}{*}{$\mathrm{Y}$} & $\mathbf{N}$ & + & + & + & + & - & + \\
\hline & $\mathbf{L S}$ & + & + & + & + & - & + \\
\hline
\end{tabular}

\begin{tabular}{|l|l|l|l|l|l|l|}
\hline $\begin{array}{l}\text { America } \\
\text { Local }\end{array}$ & & Price & $\begin{array}{l}\text { wh/wl } \\
\text { America }\end{array}$ & $\begin{array}{l}\text { wh/wl } \\
\text { Europe }\end{array}$ & Ratio & U \\
\hline & SS & 0 & + & 0 & + & - \\
\hline $\mathrm{X}$ & N & 0 & + & 0 & + & - \\
\hline & LS & 0 & + & 0 & + & + \\
\hline & SS & 0 & - & 0 & - & - \\
\hline Y & N & 0 & - & 0 & - & + \\
\hline & LS & 0 & - & 0 & - & + \\
\hline
\end{tabular}

Notation: $\mathrm{U}$ is Unemployment 